\title{
GMR
}

\section{Molecular marker-based genetic diversity analysis of scantly studied Brazilian accessions of a medicinal plant, Morinda citrifolia L. (noni)}

\author{
P.N. Bordallo, A.M.R. Monteiro, J.A. Sousa and F.A.S. Aragão \\ Embrapa Agroindústria Tropical, Fortaleza, CE, Brasil \\ Corresponding author: P.N. Bordallo \\ E-mail: patricia.bordallo@embrapa.br
}

Genet. Mol. Res. 16 (1): gmr16019531

Received November 9, 2016

Accepted December 19, 2016

Published February 23, 2017

DOI http://dx.doi.org/10.4238/gmr16019531

Copyright (C) 2017 The Authors. This is an open-access article distributed under the terms of the Creative Commons Attribution ShareAlike (CC BY-SA) 4.0 License.

ABSTRACT. Morinda citrifolia L., commonly known as noni, has
been used for the treatment of various diseases for over two centuries.
It was introduced and widely disseminated in Brazil because of its
high market value and ease of adaptation to the soil and climatic
conditions of the country. The aim of this study was to estimate the
genetic variability of noni accessions from the collection of Embrapa
Agroindústria Tropical in Brazil. We evaluated 36 plants of the 13
accessions of noni from the germplasm collection of $M$. citrifolia.
Several methods of DNA extraction were tested. After definition of the
method, the DNA of each sample was subjected to polymerase chain
reactions using 20 random amplified polymorphic DNA primers. The
band patterns on agarose gel were converted into a binary data matrix,
which was used to estimate the genetic distances between the plants and
to perform the cluster analyses. Of the total number of markers used
in this study, 125 ( $81.1 \%$ ) were polymorphic. The genetic distances
between the genotypes ranged from 0.04 to 0.49 . Regardless of the high
number of polymorphic bands, the genetic variability of the noni plants
evaluated was low since most of the genotypes belonged to the same

Genetics and Molecular Research 16 (1): gmr16019531 
cluster as shown by the dendrogram and Tocher's cluster analysis. The low genetic diversity among the studied noni individuals indicates that additional variability should be introduced in the germplasm collection of noni by gathering new individuals and/or by hybridizing contrasting individuals.

Key words: Morinda citrifolia; Genetic variability; RAPD; Polymorphic markers; Germplasm collection

\section{INTRODUCTION}

The species Morinda citrifolia L., popularly known as noni, originates from southeast Asia and has been used by the inhabitants of Polynesia for more than 2000 years for the treatment of several diseases (León and Poveda, 2000), such as high blood pressure, constipation, malaria, and even cancer (Rodríguez and Pinedo, 2004). Owing to its widespread dissemination, it is now found in various parts of the world, such as the tropical regions of Africa, the Caribbean, Australia, China, Malaysia, Indonesia, India, and some South American countries, such as Ecuador, Surinam, and Brazil (McClatchey, 2002; Correia et al., 2011). It is a species that adapts very well to coastal regions, from sea level up to $400 \mathrm{~m}$ altitude (Lübeck and Hannes, 2001) and has tolerance to saline soils and water deficit. These environmental characteristics favor Brazil as a potential producer of this species. Cultivation of noni is quite recent in Brazil, and is carried out in an empirical manner. The demand for noni is high mainly because of its high market value and the ease of obtaining seeds and seedlings, which are traded online (Sousa et al., 2010). It is grown in various states of Brazil, including Pará (Otelo, 2006), Maranhão (Silva, 2010), Sergipe, and Ceará, among others (Correia et al., 2011).

Owing to the medicinal properties attributed to it, noni has awakened the interest of producers and the pharmaceutical industry. However, there is still a lack of basic information, such as the cultivation practices, time of harvest, nutritional requirements, and genetic characterization of noni. This lack of information can compromise the quality of the final product due to the inadequate management practices. For example, the lack of information regarding the choice of the best genotype for cultivation, might limit the exploitation of genetic potential for the purpose of maximizing important characteristics of this plant.

Random amplified polymorphic DNA (RAPD) markers have been used until now to analyze the diversity, genetic relationships, and germplasm management of various species. Other markers, such as simple sequence repeat (SSR) markers, have also been used for the same purpose, but this becomes non-viable in the absence of genetic information. Other examples of the use of RAPD markers for studying genetic diversity can be cited, such as for artichoke (Sharaf-Eldin et al., 2015), bamboo (Desai et al., 2015), grass (Ghariani et al., 2015), and lemongrass (Bishoyi et al., 2016), among others. These markers have already been successfully used for studying genetic variation among the three species of noni (Singh et al., 2011) and for determining the germplasm diversity of $M$. citrifolia for plant breeding and germplasm management in India (Singh et al., 2012). However, in Brazil, no studies involving molecular markers in noni have been conducted thus far. Thus, the aim of this research was to study the magnitude of genetic divergence through RAPD markers among the accessions of noni that constitute the germplasm collection of Embrapa Agroindústria Tropical in Brazil.

Genetics and Molecular Research 16 (1): gmr16019531 


\section{MATERIAL AND METHODS}

We evaluated 36 plants from the 13 accessions of noni grown by seed from the $M$. citrifolia germplasm collection (Table 1) of Embrapa Agroindústria Tropical established in the experimental field in Pacajus, CE, Brazil. Leaves were collected from two or three plants of each accession of noni, and were immediately put in $15 \mathrm{~mL}$ tubes, and then placed in liquid nitrogen for transport to the molecular biology laboratory, where the DNA of each plant was extracted, following the protocol described by Diniz et al. (2005). The NanoDrop 2000 system (Thermo Scientific, Waltham, MA, USA) was used to quantify and evaluate the purity of the DNA.

Table 1. Plant codes and passport data of 13 accessions of noni (Morinda citrifolia L.) of the noni germplasm collection of Embrapa Agroindústria Tropical, Brazil.

\begin{tabular}{|c|c|c|c|}
\hline Plant genotype & Accession & Collection point & Place of origin \\
\hline NN01-01, NN01-02, NN01-03 & CNPAT 1 & Aracaju-SE & Paramaribo, Suriname \\
\hline NN02-01, NN02-02, NN02-03 & CNPAT 2 & Aracaju-SE & Austrália \\
\hline NN03-01, NN03-02, NN03-03 & CNPAT 3 & Tomé-Açu-PA & Japão \\
\hline NN04-01, NN04-02, NN04-03 & CNPAT 4 & Campinas-SP & Fiji \\
\hline NN05-01, NN05-02, NN05-03 & CNPAT 5 & Aracaju-SE & Paramaribo, Suriname \\
\hline NN06-01, NN06-02, NN06-03 & CNPAT 6 & Tomé-Açu-PA & Japão \\
\hline NN07-01, NN07-02, NN07-03 & CNPAT 7 & Guaiúba-CE & Unknown \\
\hline NN08-01, NN08-02 & CNPAT 8 & Fortaleza-CE & Unknown \\
\hline NN09-01, NN09-02, NN09-03 & CNPAT 9 & Uruoca-CE & Unknown \\
\hline NN10-01, NN10-02, NN10-03 & CNPAT 10 & Santa Quitéria-CE & Teresina - PI \\
\hline NN11-01, NN11-02 & CNPAT 11 & Crato-CE & Maranhão \\
\hline NN12-01, NN12-02 & CNPAT 12 & Euzébio-CE & Unknown \\
\hline NN13-01, NN13-02, NN13-03 & CNPAT 13 & Caicó-RN & Unknown \\
\hline
\end{tabular}

Polymerase chain reactions (PCR) were carried out using 20 RAPD primers (OPL01, OPA08, OPAA04, OPAA06, OPO02, OPN01, OPAB05, OPW10, OPR05, OPAB10, OPN17, OPW08, OPR06, OPW07, OPN02, OPAA03, OPAA02, OPL02, OPR07, and OPN14; Operon Technologies, Alameda, CA, USA). The PCRs were carried out in $25-\mu \mathrm{L}$ reaction volume containing 1 X PCR buffer, $6 \mathrm{mM} \mathrm{MgCl}, 2.17 \mu \mathrm{M}$ each primer, $200 \mu \mathrm{M}$ dNTP, 35 ng DNA, 1 U Taq DNA polymerase, and ultra-pure water. Reactions were carried out in the thermocycler Techne TC-512 (Techne Ltd., Cambridge, UK) adjusted for initial denaturation at $96^{\circ} \mathrm{C}$ for $3 \mathrm{~min}$, followed by 40 cycles of denaturation at $94^{\circ} \mathrm{C}$ for $45 \mathrm{~s}$, annealing at $35^{\circ} \mathrm{C}$ for $1 \mathrm{~min}$, and extension at $72^{\circ} \mathrm{C}$ for $1: 30 \mathrm{~min}$, concluding with a final extension at $72^{\circ} \mathrm{C}$ for $7 \mathrm{~min}$. The amplified fragments were separated on 1.8\% agarose gel in 1X TBE (Tris-borate-EDTA) buffer and stained with ethidium bromide, and the images were captured in an imaging system under ultraviolet light.

The patterns of the presence/absence of markers (bands) of each RAPD initiator were codified in a binary matrix in which ' 0 ' and ' 1 ' referred to the absence and presence of the marker, respectively. The polymorphism of RAPD markers was estimated by calculating the percentage of polymorphic markers with regard to the total number of fragments amplified.

The genetic distance matrix was constructed using the arithmetic complement of the Jaccard Coefficient. To determine the optimum number of amplified markers necessary for studying genetic diversity, the correlation estimates (r) and the stress value (E) were obtained from the dissimilarity matrix. The number was considered satisfactory when the correlation coefficient was ${ }^{3} 0.95$, and the stress was less than 0.05 (Kruskal, 1964). The dendrogram was constructed via the unweighted pair group method using arithmetic averages (UPGMA). The

Genetics and Molecular Research 16 (1): gmr16019531 
bootstrap analysis was also carried out to verify the consistency of the bifurcations of the dendrogram. The mean value of the genetic distance matrix was used for the separation of the clusters. Tocher's clustering method was used to analyze genetic divergence (Rao, 1952). Statistical analyses were carried out using the GENES software (Cruz, 2016).

\section{RESULTS AND DISCUSSION}

All 20 RAPD primers used in this study led to the amplification of the target DNA and exhibited polymorphism. In all, 154 bands were produced, with an average of 7.7 bands per primer. Of these, 125 bands were polymorphic $(81.1 \%)$. The number of polymorphic bands per primer ranged from 4 (OPAA2, OPAB5, and OPW8) to 11 (OPAA4).

The high number of polymorphic bands might be due to the fact that the samples were obtained from distinct plants, even when dealing with the same accession. Furthermore, although noni has been described as a preferentially self-pollinating plant (Nelson, 2003), it also has pistillate florets (Waki et al., 2008), suggesting the possibility of cross-pollination, which might be associated with high number of polymorphic bands.

Thus, in spite of the high number of polymorphic bands, the genetic variability of these noni plants was low, showing the need to gather other individuals to increase the variability in this noni germplasm collection. The reason for this was that five clusters were formed, and most of the genotypes belonged to the same cluster of the dendrogram (Figure 1). In this cluster, the magnitude of the distances between the genotypes was not sufficient to separate them into distinct clusters, showing that the high number of polymorphic bands did not result in high genetic differentiation.

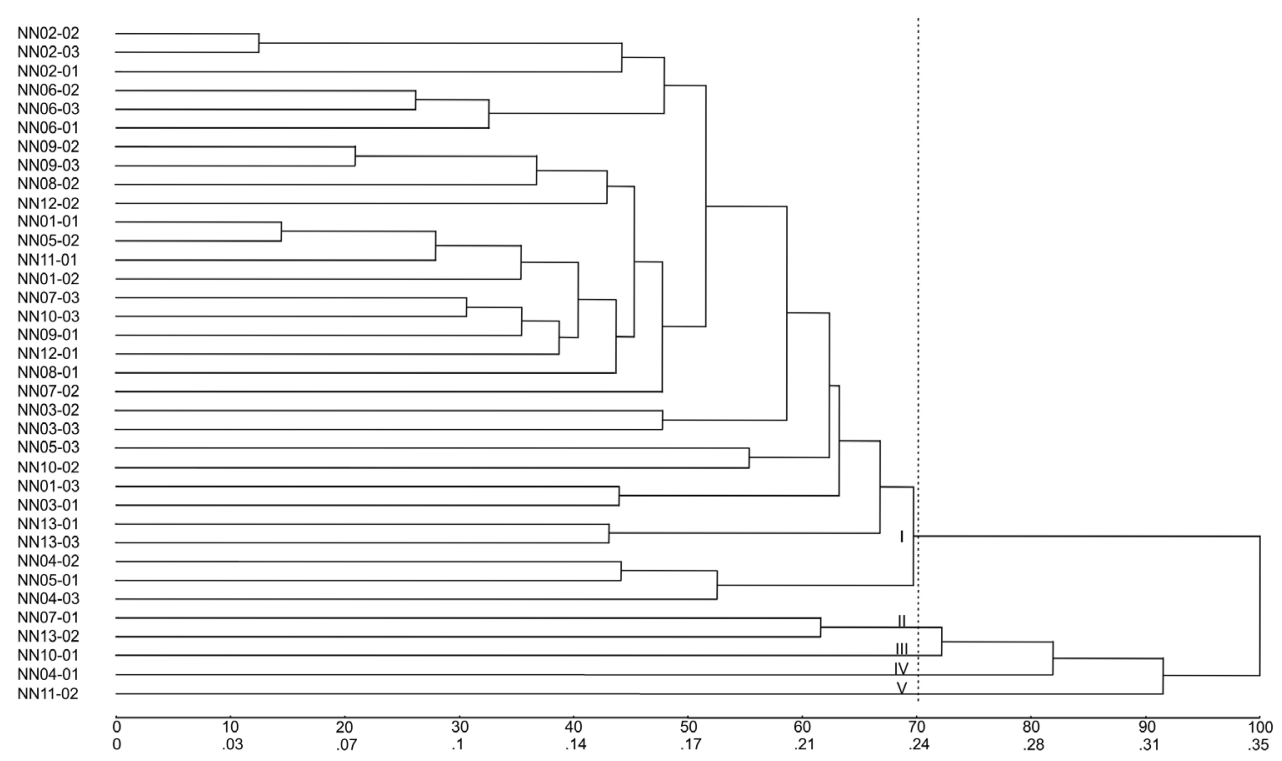

Figure 1. Clustering pattern of 36 noni genotypes of noni (Morinda citrifolia L.) from the germplasm collection at Embrapa Agroindústria Tropical, Brazil. The dendrogram was constructed by using the unweighted pair group method using arithmetic averages (UPGMA) based on Jaccard's dissimilarity coefficient. The mean value of the genetic distance matrix was used for separation of the clusters.

Genetics and Molecular Research 16 (1): gmr16019531 
Analysis of the optimum number of markers indicated that it was possible to represent the same level of genetic diversity with 96 polymorphic bands $(r=0.976 ; \mathrm{E}=0.049)$ as was defined by 129 polymorphic bands generated by the 20 RAPD primers (Figure 2). As the number of polymorphic bands (129) generated in this study was greater than the optimum number of markers (96), it can be inferred that our results were consistent.

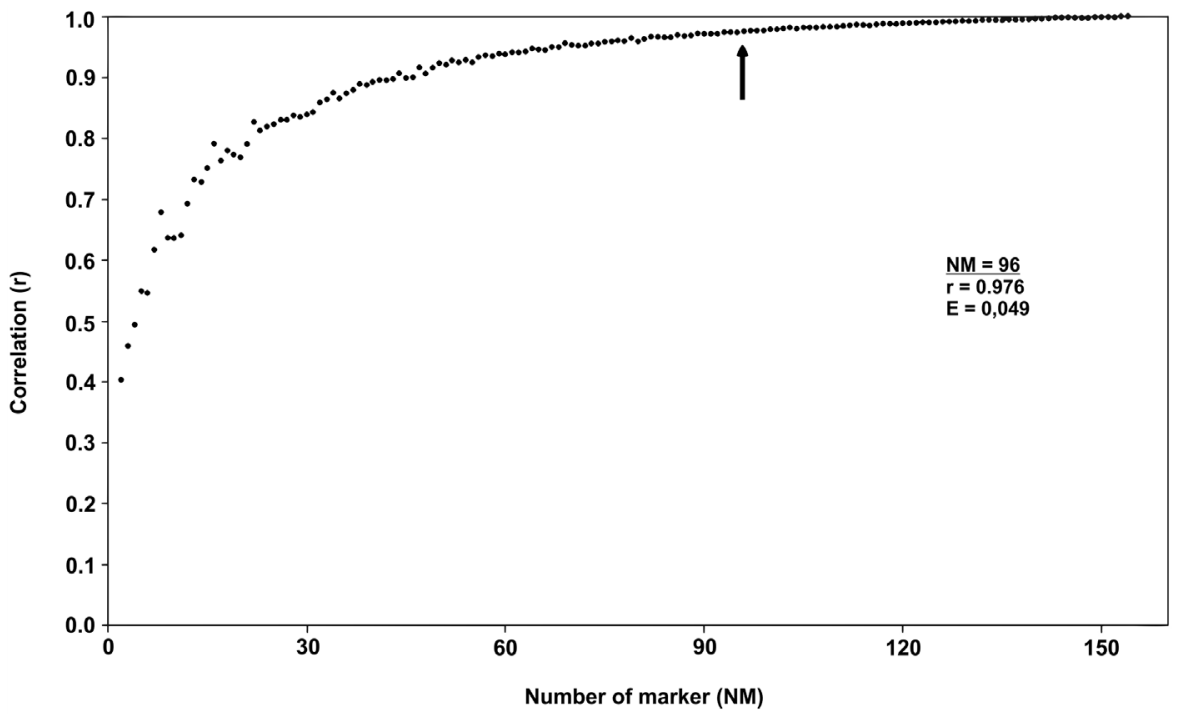

Figure 2. Analysis of the optimum number of markers based on the relationship between correlation coefficient (r) and number of fragments obtained for noni (Morinda citrifolia L.) genotypes from the germplasm collection at Embrapa Agroindústria Tropical, Brazil.

According to Tocher's cluster analysis and optimization based on genetic distances, the genotypes were arranged into four clusters of dissimilarity. Of the 36 genotypes, 31 were present in the first cluster. The genotypes NN07-01, NN13-02, and NN10-01 formed the second cluster. The third and fourth clusters were formed by the genotypes NN04-01 and NN11-02, respectively (Table 2).

Table 2. Clustering of 36 noni (Morinda citrifolia L.) genotypes from the germplasm collection at Embrapa Tropical Agroindustry based on Tocher's clustering method. The analysis were run based on Jaccard's dissimilarity matrix.

\begin{tabular}{l|l}
\hline Cluster & Genotypes \\
\hline I & NN02-02, NN02-03, NN05-02, NN01-01, NN11-01, NN06-03, NN06-02, NN06-01, NN10-03, NN01-02, NN09-03, NN08-02, NN09-01, \\
& NN12-01, NN07-03, NN08-01, NN12-02, NN07-02, NN02-01, NN09-02, NN03-02, NN03-01, NN03-03, NN13-01, NN10-02, NN05-03, \\
& NN04-03, NN01-03, NN04-02, NN13-03, and NN05-01 \\
\hline II & NN07-01, NN13-02, and NN10-01 \\
\hline III & NN04-01 \\
\hline IV & NN11-02 \\
\hline
\end{tabular}

In the dendrogram generated by the UPGMA method, the genotypes belonging to the accession CNPAT 2 (NN02-01, NN02-02, and NN02-03) remained close, in the same branch of the cluster analysis. The same can be observed for the accession CNPAT 6 (NN0601, NN06-02, and NN06-03) (Figure 1). This indicates the genetic proximity of these plants coming from the same accession, even though they were derived from distinct seeds; thus, 
they were probably half-sibs. The other clusters showed little relationship with the origin of the seeds. It should be noted that an accession is a sample of live material, which represents an individual or various individuals of a population (Walter and Cavalcanti, 2005).

The distribution of the genotypes in the dendrogram (Figure 1) was similar to that observed in the Tocher's cluster analysis (Table 2), except for the genotype NN10-01. Thus, cluster analysis by the UPGMA method and the Tocher's method were mostly in agreement, even with different criteria for classification of the genotypes. This shows the robustness of the cluster analyses formed. The bootstrap analysis also confirmed the consistency of the dendrogram. This information allows the choice of parents, aiming to implement plant breeding studies based on the evaluated germplasm.

Among the hierarchical methods, the cluster analysis by the UPGMA is the most used method in this type of study in which the separation of the clusters might vary depending on an arbitrary cut-off point. In this study, this cut-off point was defined by the mean value of the distances between all pairs of genotypes. On the other hand, the cluster analysis performed by the Tocher's method follows the optimization method, in which the clusters are mutually exclusive and independent because their calculation takes into consideration the fact that a greater genetic distance exists between the individuals of different clusters than between the individuals of the same cluster (Amaral Júnior and Thiébaut, 1999).

The genetic distance between the genotypes ranged from 0.04 (between the genotypes NN02-02 and NN02-03) to 0.49 (between the genotypes NN13-02 and NN13-03). Considering that the genotypes NN02-02 and NN02-03 belong to the same accession, the low genetic distance $(0.04)$ between them suggests that these individuals have a high degree of kinship. In contrast, the high genetic distance (0.49) between the genotypes NN13-02 and NN13-03 suggests that these genotypes came from distinct plants, even though they belonged to the same accession. The usefulness of RAPD markers in the detection of the absence of correlation between the degree of genetic similarity of the accessions and their respective origins was also reported for accessions of pitahaya, the fruit of Hylocereus undatus (Junqueira et al., 2010).

RAPD molecular markers have been successfully used in studying the degree of genetic diversity between the noni plants on the Asian continent. The studies of Singh et al. (2011), Singh et al. (2012), and Patel et al. (2014) have revealed high genetic diversity in $M$. citrifolia plants in different regions of India. This was probably due to the fact of that region being considered the center of origin of this species.

\section{CONCLUSION}

To our knowledge, this is the first report of the genetic variability of the accessions of M. citrifolia (noni) in Brazil. In this study, the evaluation of the genetic diversity of noni led to the identification of its contrasting genotypes, which can be used as parents in future gene combinations in breeding programs seeking to increase the variability in segregating populations. The genotypes NN02-02 and NN11-02 were found to be the most divergent. In addition, the evaluation of genetic diversity allowed the basis for new sampling, aiming to expand the genetic variability of the noni germplasm collection of Embrapa Agroindústria Tropical in Brazil.

\section{Conflicts of interest}

The authors declare no conflict of interest.

Genetics and Molecular Research 16 (1): gmr16019531 


\section{ACKNOWLEDGMENTS}

Research financially supported by Banco do Nordeste do Brasil and Empresa Brasileira de Pesquisa Agropecuária (Embrapa). The authors would like to express their gratitude to Andreia dos Santos Campos for editing the figures.

\section{REFERENCES}

Amaral Júnior AT and Thiébaut JTL (1999). Análise multivariada na avaliação da diversidade em recursos genéticos vegetais. Universidade Estadual do Norte Fluminense, Campos dos Goytacazes, Rio de Janeiro.

Bishoyi AK, Sharma A, Kavane A and Geetha KA (2016). Varietal discrimination and genetic variability analysis of Cymbopogon using RAPD and ISSR markers analysis. Appl. Biochem. Biotechnol. 179: 659-670. http://dx.doi. org/10.1007/s12010-016-2022-y

Correia AAS, Gonzaga MLC, Aquino AC, Souza PHM, et al. (2011). Caracterização química e físico-química da polpa de noni (Morinda citrifolia) cultivado no estado do Ceará. Aliment. Nutr. 22: 609-615.

Cruz CD (2016). Genes Software - extended and integrated with the R, Matlab and Selegen. Acta Sci. Agron. 38: 547-552. http://dx.doi.org/10.4025/actasciagron.v38i3.32629

Desai P, Gajera B, Mankad M, Shah S, et al. (2015). Comparative assessment of genetic diversity among Indian bamboo genotypes using RAPD and ISSR markers. Mol. Biol. Rep. 42: 1265-1273. http://dx.doi.org/10.1007/s11033-015-3867-9

Diniz LEC, Sakiyama NS, Lashermes P, Caixeta ET, et al. (2005). Analysis of AFLP markers associated to the Mex-1 resistance locus in Icatu progenies. Crop Breed. Appl. Biotechnol. 5: 387-393. http://dx.doi.org/10.12702/1984-7033.v05n04a03

Ghariani S, Elazreg H, Chtourou-Ghorbel N, Chakroun M, et al. (2015). Genetic diversity analysis in Tunisian perennial ryegrass germplasm as estimated by RAPD, ISSR, and morpho-agronomical markers. Genet. Mol. Res. 14: 1852318533. http://dx.doi.org/10.4238/2015.December.23.40

Junqueira KP, Faleiro FG, Junqueira NTV, Bellon G, et al. (2010). Diversidade genética de pitayas nativas do cerrado com base em marcadores RAPD. Rev. Bras. Frutic. 32: 819-824. http://dx.doi.org/10.1590/S0100-29452010005000104

Kruskal JB (1964). Nonmetric multidimensional scaling: a numerical method. Psychometrika 29: 115-129. http://dx.doi. org/10.1007/BF02289694

León J and Poveda L (2000). Nombres comunes de lãs plantas en Costa Rica. Guayacán. San José, Costa Rica.

Lübeck W and Hannes H (2001). Noni: el valioso tesoro de los mares del sur. EDAF S. A. Madrid.

McClatchey W (2002). From Polynesian healers to health food stores: changing perspectives of Morinda citrifolia (Rubiaceae). Integr. Cancer Ther. 1: 110-120, discussion 120. http://dx.doi.org/10.1177/1534735402001002002

Nelson SC (2003). Noni Cultivation and Production in Hawai'i. Proceedings of the 2002 Hawai'i Noni Conference. Honolulu, Hawaii, 33-50. Available at [http://www.ctahr.hawaii.edu/noni/downloads/noni33_50.pdf]

Otelo C (2006). Mudas de Noni. Available at [http://inforum.insite.com.br/13374/].

Patel MN, Parmer LD, Parihar A, Singh AK, et al. (2014). A high-throughput DNA extraction protocol and its utilization in molecular characterization of noni (Morinda citrifolia L.) genotypes. Curr. Trends Biotechnol. Pharm. 8: 166-174.

Rao CR (1952). Advanced Statistical Methods in Biometrical Research. John Wiley and Sons, New York.

Rodríguez FJM and Pinedo DM (2004). Mito y realidad de Morinda citrifolia L. (noni). Rev. Cuba. Plant Med. 9. Available at [http://scielo.sld.cu/scielo.php?script=sci_arttext\&pid=S1028-47962004000300002\&lng=es\&nrm=iso\&tlng=es].

Sharaf-Eldin MA, Al-Tamimi A, Alam P, Elkholy SF, et al. (2015). Genetic relatedness of artichoke (Cynara scolymus L.) hybrids using random amplified polymorphic DNA (RAPD) fingerprinting. Genet. Mol. Res. 14: 18431-18439. http://dx.doi.org/10.4238/2015.December.23.31

Silva JJM (2010). Adubação orgânica e mineral de noni: desempenho agronômico, nutrição da planta, qualidade de fruto e de suco. Doctoral dissertation, Universidade Federal da Paraíba, Areia.

Singh DR, Srivastava AK, Srivastava A and Srivastava RC (2011). Genetic diversity among three Morinda species using RAPD and ISSR markers. Indian J. Biotechnol. 10: 285-293.

Singh DR, Singh S, Minj D, Anbananthan V, et al. (2012). Diversity of Morinda citrifolia L. in Andaman and Nicobar Islands (India) assessed through morphological and DNA markers. Afr. J. Biotechnol. 11: 15214-15225.

Sousa JA, Aquino ARL, Freire FCO and Silva Neto PAF (2010). Produção de mudas de noni (Morinda citrifolia L.). Comun. Técnico 157. Embrapa Agroindústria Tropical, Fortaleza.

Waki J, Okpul T and Komolong MK (2008). Assessing the extent of diversity among noni (Morinda citrifolia L.) genotypes of Morobe Province, Papua New Guinea. S. Pac. J. Nat. Sci. 26: 11-24. http://dx.doi.org/10.1071/SP08002

Walter BMT and Cavalcanti TB (2005). Fundamentos para a coleta de germoplasma vegetal. Embrapa Recursos Genéticos e Biotecnologia, Brasília.

Genetics and Molecular Research 16 (1): gmr16019531 